\title{
Profesionalisme Dakwah Dalam Pemberdayaan Masyarakat
}

\author{
Tomi Hendra \\ Fakultas Ushuluddin, Adab dan Dakwah IAIN Bukittinggi \\ (tomihendra05@gmail.com)
}

\begin{abstract}
Da'wah is a very noble activity, where a missionary interpreter seeks to convey the message of truth to the community, with the aim of inviting the community to be able to become better in life. The missionary activities are not only limited to the delivery of religious messages, but the activities of the missionary interpreter must be realized in the form of professionalism in preaching. Da'wah is not only concerned with the interests of the group but the common interest, from this point of view the professionalism of the missionary interpreter is highly demanded, so that it does not harm other parties as the target. In the community the missionary interpreter is not limited to conveying religious messages to the community at large, but a missionary interpreter must be able to play a role in community empowerment. By playing a role as an agent of empowerment, it will increasingly appear professionalism for a missionary interpreter. This paper is to find out how professional propaganda in community empowerment. A missionary interpreter has two important roles in community life; First, as a messenger of religious messages, secondly, as agents of empowerment for the community, so that with these two important roles Islam can be integrated into community empowerment by mixing all dimensions of people's lives in it.
\end{abstract}

Keywords: Da'wah Professionalism in Community Empowerment.

\begin{abstract}
Abstrak
Dakwah merupakan aktifitas yang sangat mulia, dimana seorang juru dakwah berupaya menyampaikan risalah kebenaran kepada masyarakat, dengan tujuan mengajak masyarakat mampu menjadi yang lebih baik lagi dalam kehidupan. Aktifitas juru dakwah tidak hanya sebatas dari penyampai pesan-pesan agama, tetapi aktifitas juru dakwah ini harus diwujudkan dalam bentuk profesionalisme dalam berdakwah. Berdakwah tidak hanya mementingkan kepentingan golongan tetapi kepentingan bersama, dari sudut pandang inilah profesionalisme juru dakwah sangat dituntut, sehingga tidak merugikan pihak lain apa lagi masyarakat sebagai sasarannya. Dalam lingkungan masyarakat juru dakwah bukan sebatas dari menyampaikan pesan-pesan agama kepada masyarakat secara luas, tetapi seorang juru dakwah harus mampu berperan dalam pemberdayaan masyarakat. Dengan memainkan peran sebagai agen pemberdayaan, maka akan semakin tampak profesionalime seorang juru dakwah. Tulisan ini untuk mengetahui bagaimana propfesional dakwah dalam melakukan pemberdayaan masyarakat. Seorang juru dakwah memiliki dua peran penting dalam kehidupan bermasyarakat; Pertama, sebagai penyampai pesan-pesan agama, kedua, sebagai agen pemberdayaan bagi masyarakat, Sehingga dengan dua
\end{abstract}


peran penting ini Islam bisa teintegrasi dalam pemberdayaan masyarakat dengan bercampur segala dimensi kehidupan masyarakat di dalamnya.

Kata kunci: Profesionalisme Dakwah Dalam Pemberdayaan Masyarakat

\section{A. Latar belakang}

Dakwah sebagai usaha terwujudnya ajaran Islam pada semua segi kehidupan manusia, merupakan kewajiban bagi setiap muslim. ${ }^{1}$ Dakwah yang dilakukan oleh setiap muslim harus berkesinambungan, yang bertujuan mengubah perilaku manusia berdasarkan pengetahuan dan sikap yang benar, yakni untuk membawa manusia mengabdi kepada Allah secara total. Perjalanan dakwah sangat panjang, bahkan lebih panjang dari umur juru dakwah. Perjalanan itu dimulai jauh sebelum kita lahir ke dunia, yakni saat Allah mengutus Adam as pembawa risalah Allah yang mendakwahkan dan menegakkan kalimat tauhid (QS. 21: 25). Ciri khas dakwah, pada hakekatnya, adalah bertujuan meningkatkan keimanan dan ketaqwaan terhadap Allah.

Islam adalah agama dakwah. Islam tidak memusuhi, tidak menindas unsurunsur fitrah. Islam mengakui adanya hak dan wujud jasad, nafsu, akal dan rasa dengan fungsinya masing-masing. Dakwah dalam pengertian amar ma'ruf nahi munkar adalah syarat mutlak bagi kesempurnaan dan keselamatan hidup masyarakat. Ini merupakan kewajiban fitrah manusia sebagai makhluk sosial (makhluk ijtima'i), ${ }^{2}$ untuk mencapai tujuan ini, perlu direnungkan betapa pentingnya dakwah dalam kehidupan seorang muslim. Oleh karena itu, tidak tepat jika ada asumsi bahwa dakwah ditujukan hanya kepada orang non muslim, sedangkan orang muslim sejak lahir hidup dalam keluarga muslim, tidak lagi membutuhkan dakwah. Yang perlu dipahami bahwa dakwah harus dimulai dari diri sendiri sebelum berdakwah kepada orang lain.Oleh karena itu, berdakwah secara berkesinambungan, bukan pekerjaan yang mudah.

Berdakwah tidak cukup hanya dilakukan dengan lisan, tetapi juga harus dipraktekkan dalam bentuk perbuatan serta dakwah juga harus tampak dari sikap juru dakwah itu sendiri. Berdakwah merupakan sesuatu yang sangat penting demi tercapainya tujuan dakwah Islam. Dalam hubungan ini, seorang juru dakwah harus benar-benar memiliki akhlak yang terpuji sehingga dapat menjadi panutan dan contoh bagi yang orang-orang yang didakwahinya. Selain akhlak yang terpuji seorang juru dakwah juga harus memiliki sikap yang professional agar dakwah yang dilakukan bisa berhasil dan juga bisa melakukan aspek pemberdayaan pada masyarakat. Dakwah, kewajiban bagi umat Islam, siapapun itu. Dakwah tak pernah mengenal usia, profesi, latar pendidikan, bahasa, warna kulit, atau perbedaan apapun. Dakwah dapat dilakukan oleh siapa saja, dimana saja, kapan saja.

Frame yang baru saja dipaparkan mungkin tidak begitu berlaku saat ini. Pendakwah telah bertransformasi menjadi sebuah profesi yang berkaitan dengan profesi, tentunya tak jauh dengan uang. Hal ini tentu menyeret juru Dakwah tak lagi menjadi profesi sembarangan, karena telah bertransformasi menjadi profesi, pasti bersinggungan dengan garis-garis profesionalisme.

\footnotetext{
${ }^{1}$ Dedi Mulyana, Nuansa-Nuasa Komunikasi Masyarakat Kontemporer, (Jakarta: RemajaRosda Karya, 1999), hlm. 54

${ }_{2}$ Muhammad Natsir, Fighud Dakwah, (Dewan Dakwah Islamiah: Jakarta, 1977), hlm. 26
} 
Menjadi juru dakwah yang professional tentu harus menguasai sikap-sikap professional dunia kerja. Bila tidak, sudah pasti seseorang takkan pernah disebut pro oleh siapapun, bahkan oleh temannya sekalipun. Bila pro pekerjaannya, pro pula fiti-nya. Menilik fenomena di atas, tentunya akan menjadi sebuah masalah apabila seorang juru dakwah yang telah berulang kali naik podium dan berganti audiens tidak memiliki sikap professional sama sekali terhadap pekerjaannya. Misal, ia memberikan materi yang sama pada audiens yang berbeda-beda, dengan teknik cara penyampaian yang sama pula, akan tetapi ia disebut pro. Akan ditertawakan bila hal tersebut sampai terjadi. Jur dakwah tak tahu pola pekerjaannya, tak tahu pemecahan masalah atas pekerjaannya, dan bahkan ia tak tahu apapun selain berbicara di atas podium di depan khalayak. Berdasarkan latar belakang di atas, dalam tulisan ini, penulis akan menguraikan Profesionalisme Dakwah Dalam Pemberdayaan Masyarakat.

\section{B. Refleksi Teori}

Profesi berasal dari bahasa latin "Proffesio" yang mempunyai dua pengertian yaitu janji/ikrar dan pekerjaan. Bila artinya dibuat dalam pengertian yang lebih luas menjadi kegiatan "apa saja" dan "siapa saja" untuk memperoleh nafkah yang dilakukan dengan suatu keahlian tertentu. Sedangkan dalam arti sempit profesi berarti kegiatan yang dijalankan berdasarkan keahlian tertentu dan sekaligus dituntut daripadanya pelaksanaan norma-norma sosial dengan baik.

Profesi merupakan kelompok lapangan kerja yang khusus melaksanakan kegiatan yang memerlukan ketrampilan dan keahlian tinggi guna memenuhi kebutuhan yang rumit dari manusia, di dalamnya pemakaian dengan cara yang benar akan ketrampilan dan keahlian tinggi, hanya dapat dicapai dengan dimilikinya penguasaan pengetahuan dengan ruang lingkup yang luas, mencakup sifat manusia, kecenderungan sejarah dan lingkungan hidupnya serta adanya disiplin etika yang dikembangkan dan diterapkan oleh kelompok anggota yang menyandang profesi tersebut.

Dalam Kamus Kata-Kata Serapan Asing Dalam Bahasa Indonesia, karangan J.S. Badudu (2003), definisi profesionalisme adalah mutu, kualitas, dan tindak tanduk yang merupakan ciri suatu profesi atau ciri orang yang profesional. Sementara kata profesional sendiri berarti (1) bersifat profesi (2) memiliki keahlian dan keterampilan karena pendidikan dan latihan, (3) beroleh bayaran karena keahliannya itu. Dari definisi di atas dapat disimpulkan bahwa profesionalisme memiliki dua kriteria pokok, yaitu keahlian dan pendapatan (bayaran). Kedua hal itu merupakan satu kesatuan yang saling berhubungan. Artinya seseorang dapat dikatakan memiliki profesionalisme manakala memiliki dua hal pokok tersebut, yaitu keahlian (kompetensi) yang layak sesuai bidang tugasnya dan pendapatan yang layak sesuai kebutuhan hidupnya.

Profesionalisme berasal dan kata profesional yang mempunyai makna yaitu berhubungan dengan profesi dan memerlukan kepandaian khusus untuk menjalankannya, (KBBI, 1994). Sedangkan profesionalisme adalah tingkah laku, keahlian atau kualitas dan seseorang yang professional (Longman, 1987).

Dapat disimpulkan, profesionalisme merupakan komitmen para anggota suatu profesi untuk meningkatkan kemampuannya secara terus menerus. "Profesionalisme" adalah sebutan yang mengacu kepada sikap mental dalam 
bentuk komitmen dari para anggota suatu profesi untuk senantiasa mewujudkan dan meningkatkan kualitas profesionalnya.

Dalam bekerja, setiap manusia dituntut untuk bisa memiliki profesionalisme karena di dalam profesionalisme tersebut terkandung kepiawaian atau keahlian dalam mengoptimalkan ilmu pengetahuan, skill, waktu, tenaga, sember daya, serta sebuah strategi pencapaian yang bisa memuaskan semua bagian/elemen. Profesionalisme juga bisa merupakan perpaduan antara kompetensi dan karakter yang menunjukkan adanya tanggung jawab moral.

Istilah profesionalisme sebenarnyasudah dikenal pada zaman salafus shalih. Istilah ini, bukanlah produk abad moderen. Hanya saja urusan seperti ini belum mendapat perhatian yang memadai dikalangan para da'i dan pemimpin ummat. Seringkali kita melihat aktifitas keislaman dilakukan secara sambilan. Tanpa mengacu pada proses perencanaan (planing) yang matang.

Pengelolaan dakwah dalam pemberdayaan masyarakat kadang-kadang masih asing dalam kamus kehidupan da'i. Akibatnya, tidak akan tercapai target yang direncanakan, secara optimal. Suatu kegiatan disebut profesional apabila didukung oleh keahlian tertentu danberdasarkan kualitas tertentu, yang diperoleh dari pendidikan dan pelatihan tertentu.

Buruh bangunan misalnya, tidak disebut sebagai profesi karena hampir semua orang bisa melakukannya tanpa harus memiliki keterampilan dan keahlian. Kegiatan ini tidak disyaratkan pendidikan dan pelatihan tertentu.Oleh karena itu buruh bangunan tidak bisa disebut profesi.

Kata profesionalisme menurut S. Wojowasito berasal dari Bahasa Inggris yang berarti jabatan, pekerjaan, pencaharian, yang mempunyai keahlian.Petersalim dalam kamus bahasa kontemporer mengartikanbahwa profesi sebagai bidang pekerjaan yang dilandasi pendidikan keahlian tertentu. Dengan demikian kata profesi secara harfiah dapat diartikan dengan suatu pekerjaan yang memerlukan keahlian dan ketrampilan tertentu, dimana keahlian dan ketrampilan tersebut didapat dari suatu pendidikan atau pelatihan khusus. ${ }^{3}$

Menurut Syamsul Munir, profesionalisme adalah paham yang mengajarkan bahwa setiap pekerjaan harus dilakukan oleh orang yang professional. Ia menambhakan bahwa orang profesionalialah orang yang memiliki profesi, dan dilakaukan untuk masyarakat bukan untuk diri sendiri sserta dididukung oleh kecakapan diognostik dan kompetisi aplikatif. ${ }^{4}$

Ciri-Ciri Profesionalisme:

Seseorang yang memiliki jiwa profesionalisme senantiasa mendorong dirinya untuk mewujudkan kerja-kerja yang profesional. Kualiti profesionalisme didokong oleh ciri-ciri sebagai berikut:

1. Keinginan untuk selalu menampilkan perilaku yang mendekati piawai ideal.

2. Seseorang yang memiliki profesionalisme tinggi akan selalu berusaha mewujudkan dirinya sesuai dengan piawai yang telah ditetapkan. Ia akan mengidentifikasi dirinyakepada sesorang yang dipandang memiliki piawaian tersebut. Yang dimaksud dengan "piawai ideal" ialah suatu perangkat perilaku yang dipandang paling sempurna dan dijadikan sebagai rujukan.

${ }^{3}$ Abuddin Nata, Manajemen Pendidikan, (Jakarta: Prenada Media Group, 2010, cet. ke-4), hlm. 153

${ }^{4}$ Syamsul Munir Amin, IImu Dakwah, (Jakarta: Sinar Grafika Offsrt, 2009, cet. ke1), hlm. 126 
3. Meningkatkan dan memelihara image profesion

4. Profesionalisme yang tinggi ditunjukkan oleh besarnya keinginan untuk selalu meningkatkan dan memelihara imej profesion melalui perwujudan perilaku profesional. Perwujudannya dilakukan melalui berbagai-bagai cara misalnya penampilan, cara percakapan, penggunaan bahasa, sikap tubuh badan, sikap hidup harian, hubungan dengan individu lainnya.

5. Keinginan untuk sentiasa mengejar kesempatan pengembangan profesional yang dapat meningkatkan dan meperbaiki kualiti pengetahuan dan keterampiannya.

6. Mengejar kualiti dan cita-cita dalam profesion.

7. Profesionalisme ditandai dengan kualiti rasa bangga akan profesion yang dipegangnya. Dalam hal ini diharapkan agar seseorang itu memiliki rasa bangga dan percaya diri akan profesionnya.

Adapun aktifitas dakwah yang dilakukan secara sambilan dan nafkahnya di peroleh dari pekerjaan lain, maka kegiatan dakwah seperti ini bukan sebagai profesi dan pelakunya tidak disebut profesional. Pelaku dakwah seperti ini disebut juru dakwah amatiran. Pelaku dakwah profesional sudah tentu dituntut memiliki keahlian dan kualitas ilmu yang luas dan mendalam. Bagi mereka perlu melaksanakan kode etik profesi. Yang demikian itu sangat diperlukan karena banyak kasus penyalahgunaan agama untuk kepentingan tertentu.

Apalagi bidang garap seorang da'i adalah manusia. Jika salah dalam membina, mengasuh, mendidik dan mengarahkan serta membimbing manusia, maka akan berakibat sangat fatal. Bisa saja terjadi bahan baku yang ideal dari mad'u (obyek dakwah) menghasilkan out put yang mengecewakan. Seseorang yang semula berasal dari lingkungan baik-baik menjadi anak nakal karena salah asuh dan salah didik. Itu akibat anak didik yang diserahkan kepada orang yang bukan ahlinya. Potensi kebaikan yang dimiliki tidak tergali secara optimal, bahkan kecenderungan fujur(keburukan)-nya berkembang tanpa kendali. ${ }^{6}$

Sejarah telah membuktikan hanya para ulama'amilun (ulama yang se-ia dan sekata), orang-orang sholih dan para Nabi yang mampu mengantarkan manusia menjadi menjadi sholih, berkat petunjuk dari Allah Swt. Hanya mereka yang mampu memikul amanah tilawah, tazkiyah dan ta'lim.

Suatu hari terjadi dialog sederhana seorang sahabat dengan Rasulullah saw. Sahabat bertanya, "kapan datangnya kiamat? Jawab Rasulullah," Jika amanat sudah dikhianati." Sahabat melanjutkan, "Bagaimana mengkhianati amanat itu?" Jawab Nabi Saw," Jika suatu urusan diserahkan kepada orang yang bukan ahlinya, maka tunggulah waktu kehancuran (kiamat)." (HR. Bukhari dari Abu Hurairah).

Dakwah yang bersifat sambilan dapat dilakukan oleh semua orang. Amar ma'ruf nahi munkar adalah tugas semua muslimin. menyangkut hal itu Rasulullah Saw bersabda, "sampaikanlah dariku walau satu ayat". Dakwah dalam konteks ini tidak disyaratkan kualitas ilmu dan keterampilan tertentu. Siapa saja dan dengan posisi apapun bisa melakukannya. ${ }^{7}$

Namun bila kita mencermati kehidupan Rasulullah saw, kita bisa melihat bahwa beliau adalah seorang da'i yang profesional. Beliau adalah seorang yang ahli dan kompeten dalam bidang dakwah ini. Dan dalam berdakwah, beliau

\footnotetext{
${ }^{5}$ lbid

${ }^{6}$ Abuddin Nata, op. cit., hlm. 151-160

${ }^{7}$ Abuddin Nata, op. cit., hlm. 161
} 
melakukannya secara full timer. Beliau tinggalkan pekerjaan sebagai pedagang dan beralih sepenuhnya pada profesi barunya sebagai juru dakwah. Walaupun beliau tidak meminta upah dari pekerjaan dakwahnya, tetapi beliau dapat hidup dari profesi ini. Sebagai da'i, beliau memiliki empat potensi yang bisa di jadikan bekal dalam memikul tugasnya. Yaitu shiddiq, amanah, tabligh dan fathonah. Dua potensi yang pertama merupakan tuntutan etika dan dua potensi yang terakhir merupakan tuntutan keahlian. Seorang da'i tidak hanya dituntut memiliki kejujuran dan sikap amanah, tetapi harus memiliki keahlian komunikasi (tabligh) dan kecerdasan yang tinggi (fathonah).

Bertolak dari pemikiran di atas penulis simpulkan bahwa profesionalisme memerlukan dua persyaratan. Yaitu komitmen, loyalitas (ketaatan) dan kecintaan terhadap profesi serta keahlian yang diperoleh melalui pendidikan dan keahlian tertentu. Dua tuntutan itu bagaikan dua sisi mata uang yang tidak bisa saling dipisahkan. Bila salah satunya cacat, maka uang itu tidak akan bisa berfungsi sebagai alat tukar lagi. Jika kejujuran dan sikap mental amanah tidak lagi dijadikan pegangan dalam melakukan kegiatan profesi, sekalipun ilmu dan keahliannya selangit, maka sebagai profesional akan menemui kegagalan. Bahkan sosok seperti ini sangat membahayakan. Keahlian dan ilmu yang dimiliki digunakan untuk kepentingan pribadinya. Betapa banyak orang yang memiliki posisi strategis dengan mudah menyalah gunakan jabatan dan hak-hak istimewanya untuk interes pribadi dan golongan.

Penulis mencontohkan, Indonesia ini tidak kurang orang ahli dalam berbagai bidang. Namun ketika lembaga (Non goverment organization) dari Jerman melakukan survey yang hasilnya diterbitkanoleh sebuah majalah der spiegel mengumumkan bahwa Indonesia adalah negara paling koruptor di Asia. Memang tingkat korupsi dan kolusi di negeri kita sudah melampui batas-batas kewajaran. Bagi yang melamar pegawai negeri, mengurus surat-surat sperti KTP, SIM, Paspor, IMB dll, di kantor-kantor pemerintah, maka setiap meja yang dilalui harus diberi uang suap, sogok dan uang pelicin lainnya. Rasulullah Saw mengingatkan: Barang siapa yang bertambah ilmunya dan tidak bertambah petunjuknya tidak menambah ilmu (yang dimilikinya) kecuali jauh dari Allah. (al hadits). ${ }^{9}$

Masalahnya kemudian adalah keahlian, ilmu yang dimiliki itu tidak dibarengi sikap mental dan komitmen terhadap kode etik (tata nilai) yang telah diketahuinya secara baik. Akibatnya, prilaku mereka menjurus kepada sikap sadis dan brutal. Perbuatan seekor macanpun tidak akan tega menghabisi nyawa anaknya. Keahlian dan ilmu semata terbukti tidak menjamin seseorang bisa memberikan manfaat bagi orang lain. Bahkan aktifitas yang dilakukannya dapat mencoreng nama baiknya.

\section{Dakwah}

Dakwah secara bahasa menurutAbdul Aziz, merupakan sebuah kata dari bahasa Arab dalam bentuk masdar. Kata dakwah berasal dari kata: دعا-يدعو-دعوة

8 Ibid., hlm. 163

9 Abuddin Nata mengatakan, diantara masalah yang tidak saja merupakan isu daerah Jakarta, bahkan sudah merupakan isu nasional adalah pertentangan, konflik, dan permusuhan antara warga Matraman yang sejak dulu belum juga teratasi dengan tuntas bahkan sudah menelan jiwa dan lain sebagainya. Abuddin Nata mengatakan hal ini dalam kutipan footnote dan ini merupakan perkataannya sendiri. Ibid., h. 162 
( $d a^{\prime} a, y a d^{\prime} u$, da'watan) yang berarti seruan, panggilan, undangan atau do'a. Artinya proses penyampaian pesan-pesan tertentu berupa ajakan, seruan, undangan, untuk mengikuti pesan tersebut atau menyeru dengan tujuan untuk mendorong seorang supaya melakukancita-cita tertentu. Oleh karena itu, dalam kegiatanya ada proses mengajak yang disebut da'i dan orang yang diajak disebut mad'u. ${ }^{10}$

Sedangkan pengertian dakwah secara istilah menurut Syekh Ali Mahfudz ialah proses pemberian motivasi untuk melakukan pesan dakwah (ajaran Islam), sebagai upaya membangkitkan kesadaran manusia di atas kebaikan dan bimbingan, menyuruh berbuat ma'ruf dan mencegah kepada perbuatan munkar supaya mereka mendapat kebahagiaan di dunia dan akhirat. Definisi dari Syaikh Ali Mahfudz menawarkan penjelasan bahwa dakwah sebagai proses mendorong manusia agar melakukan kebaikan dan menuruti petunjuk, menyuruh mereka berbuat kebaikan dan melarang mereka dari perbuatan munkar agar mereka mendapat kebahagiaan di dunia dan di akhirat. ${ }^{11}$

Akan tetapi, definisi ini menurut Hamzah Ya'qub nampaknya belum dapat menjawab persoalan apa itu dakwah, sebagai pernyataan ontologis (hakikat) dakwah, sebab definisi tersebut belum memperlihatkan kejelasan tentang apa yang di cari, yaitu menemukan hakikat dari pertanyaan mengenai ke-apa-an dakwah. ${ }^{12}$ Sebab dari pernyataan nya baru mengungkapkan tentang dakwah sebagai sebuah proses komunikasi atau tabligh ajaran Islam. Untuk melengkapinya mari kia lihat penjelasan dari Sayyed Qutb. Ia mengatakan bahwa dakwah adalah mengajak atau mendorong orang untauk masuk ke dalam sabilillah, bukan yntuk mengikuti da'i atau bukan pula untuk mengikuti sekelompok orang. ${ }^{13}$

Sayyed Qutb dengan pernyataannya, seakan-akan ingin meyakinkan bahwa dalam dakwah islamiyah terdapat nilai-nilai yang universal. Definisi Sayyed Qutb tentang dakwah ini memiliki kesamaan makna dengan definisi yang di ungkapkan oleh Masdar F. Mashudi yang mengartikan dakwah islamiyah sebagai suatu proses penyadaran untuk mendorong manusia agar tumbuh dan berkembang sesuai dengan fitrahnya. ${ }^{14}$

Berdasarkan beberapa kategori definisi dakwah di atas, maka dapatlah disimpulkan bahwa dakwah Islam pada dasarnya merupakan: (1) perilaku muslim dalam menjalankan Islam sebagai agama dakwah, yang dalam prosesnya melibatkan unsur da'i, pesan dakwah, metode dakwah, media dakwah, mad'u (sasaran dakwah) dalam tujuannya melekat cita-cita ajaran Islam yang berlaku sepanjang zaman dan di setiap tempat; dan (2) proses transmisi, transformasi, dan difusi serta internalisasi ajaran Islam.

\section{Pemberdayaan Masyarakat}

${ }_{11}^{10}$ Abdul Aziz, Islah al-Wakhudu al-Diniy, (Mesir: Attiqarah al-Kubra, 1997), hlm. 26.

${ }^{11}$ Syaikh Ali Mahfudz, Hidayat al-Mursidin, (Kairo: Dar al-l'tisam, 1989, cet. Ke-9), hlm. 16. Lihat juga Abdul Kadir Sayid Abd Rauf, Dirasat fi da'wah al-Islamiyah, (Kairo: Dar al-Tiba'ah al-Mahmadiyah, 1987), hlm. 10

12 Hamzah Ya'qub, Publistik Islam, Teknik dakwah dan leadership, (Jakarta: Diponegoro, 1992), hlm. 12-20.

${ }_{14}^{13}$ Sayyed Quth, Fii Dhilalil Quran, (Beirut, Ihyaut Turatsi al-Araby, 1976), hlm. 110

14 Masdar Mashudi, Dakwah Islam Mencari Paradigma Baru, Makalah yang disampaikan pada seminar sehari tentang Politik Dakwah, di IAIN Sunan Gunung Djati Bandung, Desember 1991, hlm. 1. 
Secara leksikal istilah pemberdayaan dapat diartikan sebagai penguatan dan secara teknis istilah pemberdayaan disamakan dengan istilah pengembangan. Sedangkan secara etimologis pemberdayaan berasal dari kata "daya" yang berarti kekuatan atau kemampuan, yang maksudnya adalah sebagai suatu proses menuju berdaya atau proses memperoleh daya kekuatan atau kemampuan dalam proses memperoleh daya atau kekuatan. Dengan kata lain bisa juga kemampuan dari pihak daya kepada pihak yang kurang atau pihak yang belum berdaya. ${ }^{15}$ Kata memperoleh daya di atas menunjukkan bahwa yang menjadi sumber inisiatif untuk berdaya berasal dari masyarakat itu sendiri, atau dengan kata lain masyarakat yang mencari, mengusahakan, melakukan, menciptakan situasi atau meminta kepada pihak lain untuk memberikan daya atau kekuatan.

Menurut Mc. Ardle, sebagaimana di kutip Hery Hikmat dalam bukunya "Strategi Pemberdayaan Masyarakat", pemberdayaan diartikan sebagai sebuah proses pengambilan keputusan oleh orang-orang yang secara konsekuen melaksanakan keputusan tersebut. ${ }^{16}$ Sejalan dengan mengemukakan bahwa pemberdayaan pada intinya membahas bagaimana individu, kelompok atau pun komunitas berusaha mengontrol kehidupan mereka sendiri dan mengusahakan untuk membentuk masa depan sesuai dengan keinginan mereka.

Apabila ini disamakan dengan pengembangan masyarakat maka maksudnya adalah "Suatu usaha yang digambarkan dalam berbagai bentuk kegiatan dengan tujuan menyadarkan masyarakat agar menggunakan dengan lebih baik semua kemampuan yang dimilikinya, baik dalam bentuk potensi alam maupun tenaga serta menggali inisiatif masyarakat setempat untuk lebih banyak melakukan kegiatan dan investasi guna mencapai tingkat hidup yang lebih tinggi. Pengembangan dalam pengertian yang lain adalah suatu upaya memperluas horizon pilihan bagi masyarakat, maka dalam hal ini masyarakat diberdayakan untuk melihat dan memilih sesuatu yang bermanfaat bagi dirinya.

Dalam tinjauan historis, istilah pengembangan masyarakat (community development) diadopsi dari bangsa Inggris di mana kantor pemerintah Inggris mengeluarkan suatu memorandum yang berisikan tentang cara untuk meninggkatkan kesejahteraan kehidupan masyarakat di daerah jajahan bangsa Inggris, yang disebut dengan "pengembangan masyarakat".

Pada tahun 1944 memorendum tersebut dikeluarkan berisikan tentang tiga kebijakan, yaitu: tentang peningkatan kondisi kehidupan dan kesejahteraan masyarakat, peningkatan taraf hidup ekonomi masyarakat dan pengembangan institusi dan kekuatan politik.

Dengan demikian, dari beberapa pengertian di atas dapat dimengerti bahwa yang dimaksud pemberdayaan masyarakat adalah suatu usaha yang digambarkan dalam berbagai bentuk kegiatan yang nyata di tengah masyarakat. Dengan tujuan menyadarkan masyarakat agar dapat menggunakan serta memilih kehidupannya untuk mencapai tingkat hidup yang lebih baik dalam segala segi kehidupan. Pemberdayaan dimaksudkan pada hakikatnya adalah sebagai upaya peningkatan kualitas maupun kuantitas kehidupan manusia. Pemberdayaan juga berarti perubahan suatu masyarakat ke arah yang lebih baik dalam rangka mencapai

${ }^{15}$ Ambar Teguh Sulistiani, Kemitraan dan Model Pemberdayaan, (Yogyakarta: Gava Media, 2004), hlm. 77

${ }_{16}$ Harry Hikamat, Strategi Pemberdayaan Masyarakat, (Bandung: Humaniora Utama Press, 2004, Cet, Ke-2), hlm.3 
tujuan yang dicita-citakan yaitu meningkatkan taraf hidup, kemakmuran, dan kesejahteraan seluruh rakyat baik materil maupun spiritual. Sementara dalam perspektif Islam, menurut M.Quraish Shihab konsep pembangunan bersifat menyeluruh, menyentuh dan menghujam kedalam jati diri manusia, dengan demikian ajaran tersebut dapat membangunan manusia seutuhnya, baik dari segi materil dan spiritual secara bersamaan. ${ }^{17}$

Sementara itu, untuk mewujudkan tujuan dakwah khususnya dalam konteks pemberdayaan maka menurut Mansour Fakih, orientasi, metode dan meteri dakwah harus menuju karakteristik pengembangan yaitu: Pertama adanya komitmen yang kuat dari juru dakwah pada masyarakat yang akan dilembagakan. $K e d u a, d a ' i$ dan masyarakat harus semakin dekat persamaan visi, karena $d a{ }^{\prime} i$ bukan sekedar bertugas menyampaikan akan tetapi menjadi jembatan untuk memfasilitasi masyarakat. Ketiga, isi dakwah bukan lagi tentang uraian masalah masyarakat yang harus dipecahkan oleh pihak lain, akan tetapi memfasilitasi masyarakat agar mampu memahami diri, masalah dan potensi mereka, untuk suatu proses transformasi baik dari aspek sosial, politik, dan psikologi menuju yang dikehendaki masyarakat. Keempat, dakwah harus mampu menciptakan suasana bahwa masyarakat memiliki kemampuan dan potensi untuk memproduksi pengetahuan dan menganalisisnya. ${ }^{18}$

Penulis menegaskan bahwa pemberdayaan dalam konteks dakwah adalah seruan atau ajakan kepada keinsyafan atau usaha untuk mengubah situasi yang lebih baik dan sempurna, baik terhadap pribadi maupun masyarakat. Perwujudan dakwah bukan sekedar pada usaha peningkatan pemahaman keagamaan dalam tingkah laku dan pandangan hidup saja, akan tetapi harus menuju sasaran yang luas yaitu harus lebih berperan menuju pelaksanaan ajaran Islam secara menyeluruh dalam berbagai aspek kehidupan

Fungsi dakwah jika dilihat dari targetnya, menurut Al-Yasa Abu Bakar sebagaimana dikutip oleh Muhammad Sulthon dalam bukunya Desain Ilmu Dakwah, dapat dibedakan menjadi $4 \mathrm{Hal}$, yaitu: ${ }^{19}$

a. I'tiyadi, yaitu ketika target dakwah adalah normalisasi tatanan nilai yang telah ada, hidup dan berkembang di suatu komunitas, dengan demikian dakwah yang disampaikan agar tata nilai itu kembali kepada yang sesuai dengan nilai-nilai keislaman.

b. Muharriq, yaitu ketika target dakwah itu berupa peningkatan tatanan sosial yang sebenarnya sudah islami agar semakin meningkat lagi nilai-nilai keislamannya hidup dalam komunitas tersebut.

c. Iqaf, yaitu ketika target dakwah sebagai upaya preventif dengan sejumlah petunjuk-petunjuk dan peringatan-peringatan yang relevan agar komunitas tersebut tidak terjerumus kedalam tatanan yang tidak Islami atau kurang mencerminkan nilai-nilai keislaman.

${ }^{17}$ M. Quraish Shihab, Membumikan Al-Qur'an: Fungsi dan Peran Wahyu Dalam Masyarakat, (Bandung: Mizan, 2004,Cet.Ke-18), hlm.301

${ }_{18}$ Mansour Fakih, Dakwah Siapa Yang Diuntungkan, (Jakarta: P3M Pesantren No.04/Vol/1987), hlm.11

${ }^{19}$ Muhammad Sulthon, Desain IImu Dakwah, Kajian Ontologis, Epistemologis dan Aksiologis, (Semarang: WaliSongo Press, 2003), hlm.140-141 
d. Tahrif, yaitu ketika target dakwah sebagai upaya membantu untuk ikut meringankan beban penderitaan akibat problem-problem yang secara ril telah mempersulit kehidupan komunitas.

\section{Penutup:}

Professionalisme juru dakwah memang sangat dituntut, terutama di era ini. Mereka yang berdakwah, terutama menjadikan dakwah sebagai ladang mencari makan mesti memiliki sikap dan rasa yang baru saja dijelaskan secara singkat mungkin padat di atas. Ada kalanya, seorang juru dakwah menjadi ramah pada jemaahnya, ada kalanya pula ia menjadi tegas dalam berdakwah, itu semua tergantung pada medan dakwah yang tengah ia hadapi dan sikap professional itulah kemudian yang akan membimbingnya.

Seorang juru dakwah harus memiliki visi dan nilai moral yang tinggi. Ia tidak hanya menjadi figure pertunjukan di atas panggung, tak hanya menyajikan tawa, tangis dan keduanya bersamaan. Juru dakwah lebih dari itu semua, ia adalah seorang figure yang perilakunya akan diteladani oleh siapapun. Bila ia baik, mereka akan mengikutinya, bila sebaliknya, jangan harap. Maka dari itu seorang jur dakwah mesti memiliki visi dan nilai moral yang tinggi.

Selain itu semua, dai pun dituntut untuk senantiasa selalu bersikap professional dalam pekerjaannya. Ia dituntut untuk menguasai pekerjaaanya, memiliki motivasi, komitmen, loyalitas dan hal lainnya. Itu semua akan menunjang pekerjaannya sebagai seorang juru dakwah yang professional.

\section{Rujukan}

Abuddin Nata, Manajemen Pendidikan, Jakarta : Prenada Media Group, 2010, cet. ke-4

Syamsul Munir Amin, Ilmu Dakwah, Jakarta, Sinar Grafika Offsrt, 2009, cet. ke-1 Abdul Aziz, Islah al-Wakhudu al-Diniy, Mesir: Attiqarah al-Kubra, 1997)

Syaikh Ali Mahfudz, Hidayat al-Mursidin, Kairo : Dar al-I'tisam, 1989, cet. KeAbdul Kadir Sayid Abd Rauf, Dirasat fi da'wah al-Islamiyah, Kairo: Dar alTiba'ah al-Mahmadiyah, 1987

Hamzah Ya'qub, Publistik Islam, Teknik dakwah dan leadership, Jakarta: Diponegoro, 1992, ttn

Sayyed Quth, Fii DhilalilQuran, Beirut, Ihyaut Turatsi al-Araby, 1976, ttn. J. 7

Masdar Mashudi, Dakwah Islam Mencari Paradigma Baru, Makalah yang disampaikan pada seminar sehari tentang Politik Dakwah, di IAIN Sunan Gunung Djati Bandung, Desember 1991, ttn.

Ambar teguh Sulistiani, Kemitraan dan model pemberdayaan, (Yogyakarta : Gava media, 2004)

Harry Hikamat, Strategi Pemberdayaan Masyarakat, (Bandung : Humaniora Utama Press, 2004)Cet, Ke-2

Sutrisno Kh dan Mary Johnston, Membina Masyarakat Pembangunan KasusKasus Pengembangan Masyarakat, (Surakarta : Yayasan Indonesia Sejahtera, 1992. 